\title{
Analysis and application of energy absorption characteristics of expansion tube type absorber
}

\author{
Hang Yin ${ }^{1, a}$, Xiaolong Zhang ${ }^{2}$, Yu Zhang $^{3}$ \\ ${ }^{1}$ School of mechanical and electrical engineering, Northeast Forestry University, Harbin, Heilongjiang Province, China \\ ${ }^{2}$ Fluid-solid coupling laboratory, Harbin Engineering University, Harbin, Heilongjiang Province, China \\ ${ }^{3}$ Research institute of internal and external decoration, Great Wall motor co. LTD, Bao Ding, Hebei Province, China
}

\begin{abstract}
Passive safety protection technology is to reduce the damage caused by collision by improving the anti-impact performance of the system itself. It has important engineering practical value. Many scholars have carried out the research on the collision design of the train in the structure design of the track vehicle. The core is to absorb the kinetic energy of the collision by absorbing energy structure to reduce the force generated during the collision and minimize casualties. The expansion tube type absorber is usually used as a collision safety protection device in the track vehicle. The quasi-static compression test is carried out for the expansion tube type absorber. The energy absorption characteristics and compression characteristics of the expansion tube energy absorber in quasi-static compression test are studied experimentally. The design and research of the energy absorber for rail vehicles are of guiding significance and practical value.
\end{abstract}

\section{Introduction}

The front end of the rail train is usually equipped with a buffer absorber. The energy absorption structure can absorb energy through plastic deformation, such as honeycomb, foam, thin wall structure folding and expansion of thin wall structure [1]. There is also the fracture of the composite material, the friction of the structure and the viscous dissipation energy. Because the expansion tube buffer is easy to process and adjust, what's more, it has work stability and other advantages [2]. Tube expanding shock absorber is often applied to the coupler buffer device and rail transit anti-creeper as part of the passive safety systems in the buffer energy absorption and prevent train climbing and overthrow the collision process. Therefore, it is very important to study the energy absorption device. The quasi-static axial compression test is easier to implement, control and record the compression process. In this study, the quasistatic compression test was first performed because of the same failure mode of the expansion tube absorber in the dynamic impact test and the quasi-static compression test. Main validation test feasibility, determine the test sample material, process and test method [3].

\section{EXPANSION PIPE ENDERGONIC QUASI-STATIC COMPRESSION TEST}

\subsection{Test preparation}

Because the expansion tube type absorber mainly absorbs energy through the expansion tube metal deformation. The material selection of expansion tube should be characterized by good plasticity, stable mechanical properties and more than $20 \%$ material elongation. The expanded pipe material of this test use 20\#. In order to ensure the plastic deformation of the expansion tube during the work of the expansion tube, the cone head does not have plastic deformation. The modified $45 \#$ material will ensure that its strength and hardness are enough to be greater than 20\#. Therefore, $45 \#$ is used as the cone head material [4]. The test equipment used in this experiment is $20000 \mathrm{kN}$ automatic servo press, as shown in figure 1 . A section view of the actual structure of an expansion tube type absorber is shown in figure 2. Details of expansion tube and cone head is shown in table1 and table 2 .

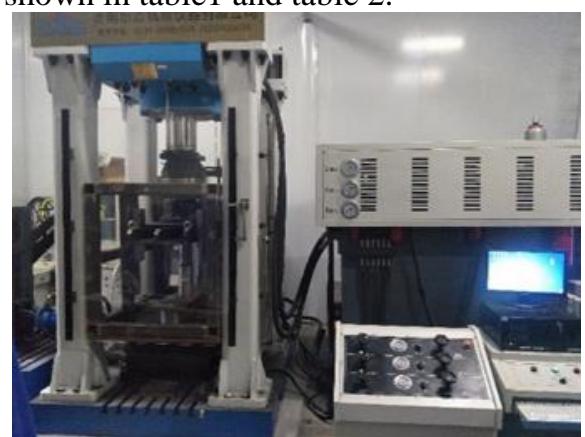

Figure 1 Fully automatic servo press 


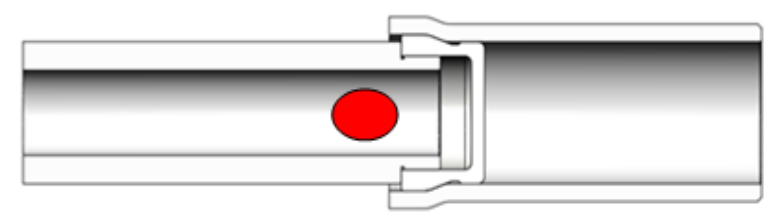

Figure 2 A section view of the actual structure of an expansion tube type absorber

Table 1 Expansion tube list

\begin{tabular}{|c|c|c|c|c|c|}
\hline $\begin{array}{c}\text { Tube } \\
\text { expandin } \\
\mathrm{g}\end{array}$ & materials & $\begin{array}{c}\text { inner } \\
\text { diamet } \\
\mathrm{er}\end{array}$ & $\begin{array}{c}\text { thickne } \\
\mathrm{ss} \\
(\mathrm{mm}\end{array}$ & $\begin{array}{c}\text { length } \\
(\mathrm{mm} \\
)\end{array}$ & $\begin{array}{c}\mathrm{a} \\
\mathrm{m} \\
\mathrm{o}\end{array}$ \\
\hline SY1-1 & $\begin{array}{c}\text { Normalizin } \\
\mathrm{g} 20 \#\end{array}$ & 100 & 5 & 250 & 3 \\
\hline SY1-2 & $\begin{array}{c}\text { Normalizin } \\
\mathrm{g} 20 \#\end{array}$ & 100 & 6 & 240 & 3 \\
\hline SY1-3 & $\begin{array}{c}\text { Quenching } \\
\text { 20\# }\end{array}$ & 100 & 6 & 250 & 3 \\
\hline
\end{tabular}

Table 2 Cone head list

\begin{tabular}{|c|c|c|c|c|}
\hline $\begin{array}{c}\text { Cone } \\
\text { head } \\
\text { number }\end{array}$ & $\begin{array}{c}\text { materia } \\
1 \mathrm{~s}\end{array}$ & $\begin{array}{c}\text { half cone } \\
\text { angle/ } \\
\left({ }^{\circ}\right)\end{array}$ & $\begin{array}{c}\text { external } \\
\text { diameter } \\
(\mathrm{mm})\end{array}$ & amount \\
\hline SY1-ZT1 & $\begin{array}{c}\text { Quench } \\
\text { ing 45\# }\end{array}$ & 20 & 120 & 1 \\
\hline
\end{tabular}

\subsection{Test procedure}

Tighten the cone and taper pipe oThe molybdenum disulphide grease is applied uniformly on the outer surface of the cone head and the inner wall of the expansion tube. Put the taper pipe fitting into the expansion tube and place it in the center of the press. Set the compression speed to $10 \mathrm{~mm} / \mathrm{min}$ and the compression stroke $180 \mathrm{~mm}$. Record the expansion of expansion tube in each experiment. After the test, each component dimension data is measured and retained.

\subsection{Test results}

Figure 3 is a real picture of the conical head specimen after the inner wall surface and compression test of the expansion tube with expanded diameter after three groups of tests. It can be seen from the inner wall surface of the expanded tube specimen that there is slight scratch in the inner wall of the compressed expansion tube. After compression test, there was no obvious scratch in the shape of the cone head, no difference between the size and the test.

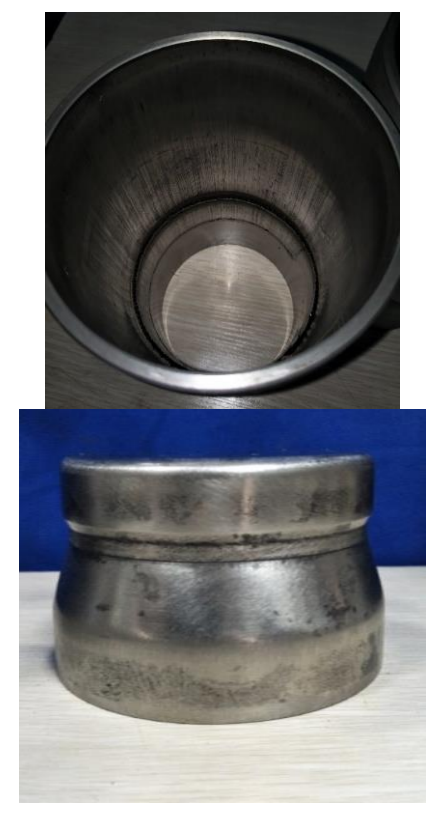

A) Inner wall of the expansion B) Cone head after the test tube after the test

Figure 3 Surface status of the parts after the test

Figure 4 is three groups of expansion tube type energy absorbers test physical pictures. According to the appearance of expansion tube expansion and expansion tube of the first two groups, it can be seen that the expansion process of expansion tube is smooth, and there is no buckling or rupture of expansion tube. However, by observing the third group of experiments, the metal collision and tearing sound can be heard clearly in the compression process. Meanwhile, a sample of the sample in this group is directly fractured during the compression process.

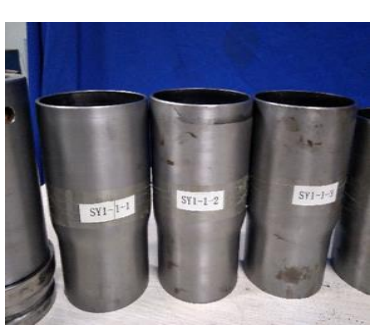

A) SY1-1 test

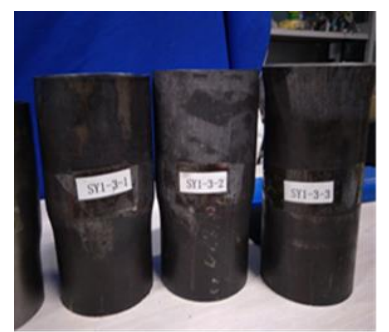

C) SY1-3 test
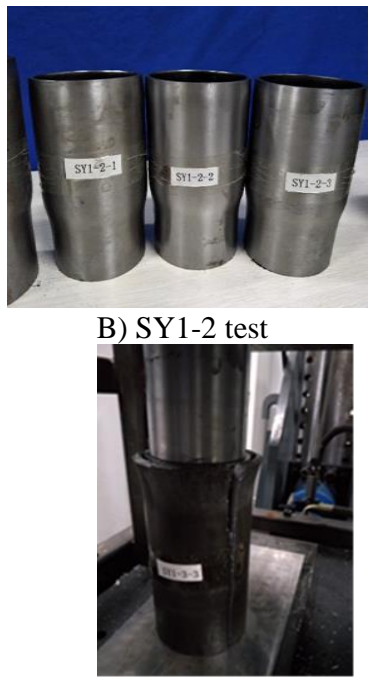

D) SY1-3-3 test
Figure 4 Test physical pictures of the three groups of expansion tube energy absorbers.

Figure 5 and figure 6 are the buffer force displacement curves of SY1-1 and SY1-2 respectively. As the test specimen of SY1-3 is fractured during the test, no data analysis is conducted. 


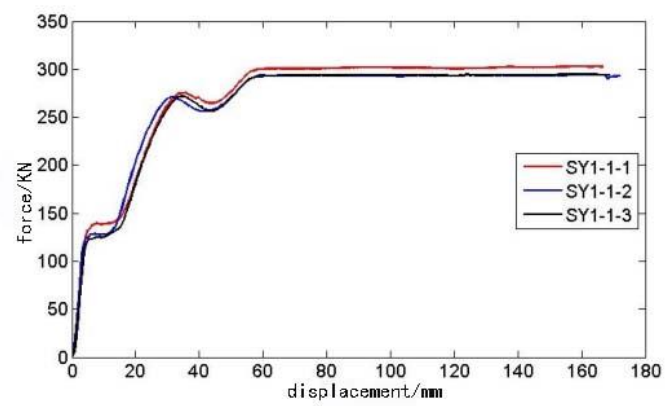

Figure 5 Test SY1-1

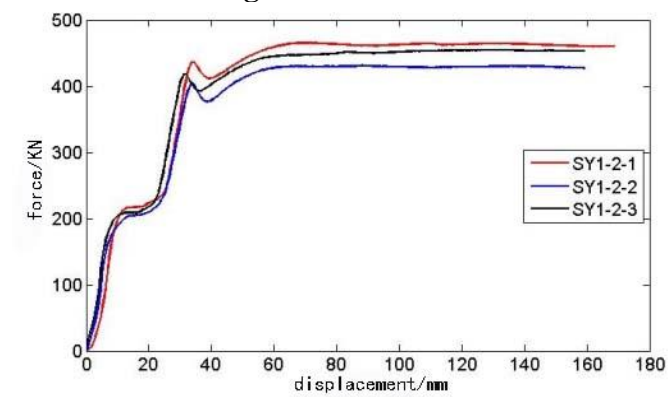

Figure 6 Test SY1-2

\section{Analysis of test results}

Comparing SY1-1,SY1-2 and SY1-3 test, the heat treatment method of the specimen plays a decisive role in the feasibility of the test. The test pieces of SY1-1 and SY1-2 are all positive heat treatment. The SY1-3 test piece is the quenching heat treatment method. The specimen is hardened after quenching and then becomes brittle at the same time [5]. The whole fracture occurs when pressure is applied to press the cone head into the expansion tube. Therefore, the heat treatment method of expansion tube is in hot treatment. Test process is stable and smooth, the buffer force - displacement curve smooth and no obvious fluctuations, compressed expansion pipe wall does not appear on injury, scratches, etc., as well as the cone head does not appear and the expansion pipe jammed, and so on and so forth. In the above experiments, repeated experiments were conducted with three groups of identical test samples, with no significant difference in the buffer force and displacement curve, and the test repeatability was good. The compression stroke of the buffer force displacement curve is about $70 \mathrm{~mm}$. It can be seen from the comparison between figure 5 and figure 6 that with the increase of wall thickness, the greater the buffer force after smooth. The buffer force size of the buffer force and displacement curve of the two groups of tests is different, but the wall thickness difference between the two groups is not big, and the difference is only $1 \mathrm{~mm}$. It can be concluded that the value of buffering force is sensitive to the change of wall thickness.

\section{Conclusion}

Expansion pipe using $20 \#$ is heat treatment, the cone head adopt 45\# and tempering heat treatment, conforming to the requirements of the expansion that tube can absorb energy, metal deformation in good condition, the compression process smooth, no obvious scratches on metal surface injury etc. And the buffer force - displacement curve is smooth and smooth, and the material selection of the absorber is reasonable, which can be used as the guide for practical engineering problems. From experimental observation on the compression stroke up to $70 \mathrm{~mm}$, the test basic stable income buffer force - displacement curve no longer increases, so the follow-up study do a similar test, this trip as a design reference, sparing parts can save the processing cost, shorten production cycle.

\section{References}

1. British Standards. Railway applications crashworthiness requirements for railway vehicle bodies, in BS EN 15227:2008+A1:2010.

2. Ahn K, Kim JS, Huh H. The effects of local buckling on the crash energy absorption of thinwalled expansion tubes. In Numisheet 2008. 2008. Interlaken, Switzerland.

3. Yang J, Luo M, Hua Y, Lu G. Energy absorption of expansion tubes using a conical-cylindrical die: experiments and numerical simulation. Int $\mathrm{J}$ Mech Sci 2010;52(5):716-25.

4. Karrech A, Seibi A. Analytical model for the expansion of tubes under tension. J Mater Process Tech 2010;210(2):356-62

5. Almeida BPP, Alves ML, Rosa PAR, Brito AG, Martins PAF. Expansion and reduction of thinwalled tubes using a die: experimental and theoretical investigation. Int J Mach Tools Manuf 2006;46(12-13):1643-52. 